\title{
THE 2013 FINDS IN THE CONTEXT OF THE ANIMAL STYLE OF THE KURGAN 1 OF THE NECROPOLIS FILIPPOVKA 1
}

\author{
Konstantin S. Okorokov \\ Institute of Archaeology of the Russian Academy of Sciences, Moscow, Russian Federation \\ Elena V. Perevodchikova \\ Institute of Archaeology of the Russian Academy of Sciences, Moscow, Russian Federation
}

\begin{abstract}
The article deals with the specimens of Scythian Animal Style found in 2013 during supplementary excavation of the kurgan 1 of the necropolis Filippovka 1 (previously it was called the $1^{\text {st }}$ Filippovka kurgan) in 2013. The specimens of the Scythian Animal Style analyzed were found in a new excavated burial 2. There were found golden plaques of wooden vessels with zoomorphic handles, silver mirror with gilded handle. There are images of animals on the golden plaques for a dress, some pendants and finger rings. The works of Art described show many stylistic parallels with the specimens of the Animal Style previously found in the mound. Comparing the items we have found some specific features of Scythian Animal Style of the $1^{\text {st }}$ Filippovka kurgan. Among new finds we see also unique ones. In recent years the figures of deer embroidered on sleeves of the dress were found by V.E. Tregubov and K.S. Okorokov. We present the first publication of the research results by K.S. Okorokov reconstructed these figures of deer. These figures also find stylistic parallels with the works of Art of the $1^{\text {st }}$ Filippovka kurgan. Some works of Achaemenid Art contain elements of Scythian Animal Style. The Style of these items also shows some characteristics specific for Scythian Animal Style of the kurgan 1 of the necropolis Filippovka 1. Basing on this we can suggest they were made by Achaemenid craftsmen by order from Filippovka nomads. Our work confirms the thesis of stylistic unity of the works of Art found in the $1^{\text {st }}$ Filippovka kurgan.

Key words: Scythian Animal Style, $1^{\text {st }}$ Filippovka kurgan, kurgan 1 of the necropolis Filippovka 1, reconstruction of a dress, specific features of Animal Style of the $1^{\text {st }}$ Filippovka kurgan, Achaemenid craftsmen work for nomads.

Citation. Okorokov K.S., Perevodchikova E.V., 2020. The 2013 Finds in the Context of the Animal Style of the Kurgan 1 of the Necropolis Filippovka 1. The Lower Volga Archaeological Bulletin, vol. 19, no. 1, pp. 28-45. (in Russian). DOI: https://doi.org/10.15688/nav.jvolsu.2020.1.2
\end{abstract}

\section{НАХОДКИ 2013 Г. В КОНТЕКСТЕ ЗВЕРИНОГО СТИЛЯ КУРГАНА 1 КУРГАННОГО МОГИЛЬНИКА ФИЛИППОВКА 1}

\author{
Константин Сергеевич Окороков \\ Институт археологии РАН, г. Москва, Российская Федерация \\ Елена Владимировна Переводчикова \\ Институт археологии РАН, г. Москва, Российская Федерация
}

Аннотация. В статье идет речь о произведениях скифского звериного стиля, найденных при доследовании кургана 1 курганного могильника Филипповка 1 (ранее он назывался «1-й Филипповский курган») в 2013 году. Анализируемые предметы в скифском зверином стиле происходят из вновь раскопанного погребения 2. Здесь найдены золотые оковки деревянных сосудов с зооморфными ручками, к одному из которых относилась роговая крышка с ручкой в форме птичьей головы, серебряное зеркало с позолоченной ручкой, 
оформленной в зверином стиле. Зооморфные изображения присутствуют и на золотых нашивках на одежду погребенной, золотых височных подвесках, золотых перстнях и на некоторых привесках к одному из браслетов. Описанные произведения искусства находят много стилистических параллелей с предметами, обнаруженными в кургане прежде. Сравнивая предметы, мы выявили некоторые специфические черты звериного стиля кургана 1 курганного могильника Филипповка 1. Среди новых находок есть и уникальные. В недавнее время на рукавах одежды В.Е. Трегубовым и К.С. Окороковым были обнаружены фигуры оленей. В статье впервые публикуются результаты исследования К.С. Окорокова, реконструировавшего эти фигуры. Они также находят стилистические параллели с произведениями искусства из кургана 1 курганного могильника Филипповка 1. В составе некоторых предметов ахеменидского производства имеются элементы, выполненные в скифском зверином стиле, а также прослеживаются специфические черты звериного стиля Филипповки. Поэтому мы можем предположить, что они сделаны ахеменидскими мастерами по заказу кочевников Филипповки. Наша работа подтверждает тезис о стилистическом единстве произведений искусства из 1-го Филипповского кургана.

Ключевые слова: скифский звериный стиль, 1-й Филипповский курган, курган 1 курганного могильника Филипповка 1, реконструкция костюма, специфика звериного стиля 1-го Филипповского кургана, работа ахеменидских мастеров для кочевников.

Цитирование. Окороков К. С., Переводчикова Е. В., 2020. Находки 2013 г. в контексте звериного стиля кургана 1 курганного могильника Филипповка $1 / /$ Нижневолжский археологический вестник. Т. 19, № 1. C. 28-45. DOI: https://doi.org/10.15688/nav.jvolsu.2020.1.2

Знаменитый курган 1 курганного могильника Филипповка 1 (ранее он назывался «1-й Филипповский курган» ${ }^{1}$ ), раскопанный в 1988 г. экспедицией под руководством А.Х. Пшеничнюка, в 2013 г. был доследован Южноуральской экспедицией ИА РАН под руководством Л.Т. Яблонского. Под восточной полой кургана было раскопано не тронутое грабителями богатейшее погребение 2 , а также захоронения лошадей и жертвенные комплексы [Яблонский, 2014a, с. 4-7].

Среди находок присутствует серия вещей, оформленных в скифском зверином стиле. Подавляющее их большинство происходит из погребения 2. Здесь найдены золотые оковки деревянных сосудов с зооморфными ручками [Яблонский, 2014a, рис. II, 1; 2014в, с. 2526; 2014г, рис. 77-78, 149-151], к одному из которых относилась роговая крышка с ручкой в форме птичьей головы [Яблонский, 2014г, рис. 75, 76], серебряное зеркало с позолоченной ручкой, оформленной в зверином стиле [Яблонский, 2014a, рис. II,3]. На расшитых бисером рукавах одежды погребенной недавно удалось выявить фигуры оленей. Зооморфные изображения присутствуют и на золотых нашивках на одежду погребенной, золотых височных подвесках, золотых перстнях [Яблонский, 2014a, рис. III; 2014в, рис. 186188] и на некоторых привесках к одному из браслетов [Яблонский, 2014г, рис. 192-193]. В зверином стиле оформлены также две кос- тяные ложечки [Яблонский, 2014г, рис. 100101, 132; Аникеева, Яблонский, 2018, рис. 2,45] и предметы конской узды [Яблонский, 2014г, рис. 161-163]. В подземном ходе был найден котел с зооморфными ручками [Яблонский, 2014a, с. 4; 2014в, рис. 54-57].

Наша задача - рассмотреть эти предметы в контексте уже известных произведений скифского звериного стиля из 1-го Филипповского кургана.

К сожалению, Л.Т. Яблонский не успел подробно опубликовать материалы раскопок 2013 года. Имеется лишь краткое изложение результатов работ [Яблонский, 2014a, 2014б] и статьи о некоторых интересующих нас предметах ахеменидского происхождения [Яблонский, 2016; Аникеева и др., 2017; 2018 ]. Однако в этих кратких публикациях представлена достаточно выразительная серия вещей. Мы будем также обращаться к тексту и альбому отчета о раскопках кургана [Яблонский, 2014в; 2014г].

После того как полученные археологические материалы были сданы в Оренбургский краеведческий губернаторский музей, старшим научным сотрудником музея В.Е. Трегубовым в довольно хаотичной (на первый взгляд) картине расположения бисера и мелких бусин на рукавах одежды была выявлена фигура оленя. Это побудило одного из авторов данной статьи провести работу над графической реконструкцией фрагментов одежды, попытав- 
шись выявить все возможные изображения на данном объекте.

Доклад о результатах проведенного исследования был сделан К.С. Окороковым 13 ноября 2019 г. на заседании круглого стола «Археология ранних кочевников евразийской степи: актуальные проблемы и перспективы их решения» (к юбилею д-ра ист. наук М.Г. Мошковой) в Институте археологии РАН. По материалам выступления автором подготовлена к печати статья «Расшитые бисером рукава женского костюма из погребения 2 кургана 1 некрополя Филипповка 1». Детальные описания результатов будут даны также в отдельной совместной статье К.С. Окорокова и В.Е. Трегубова.

За годы, прошедшие между раскопками А.Х. Пшеничнюка и Л.Т. Яблонского, произведения искусства, найденные в кургане, неоднократно привлекали внимание исследователей. Яркие и выразительные, в большинстве своем уникальные предметы экспонировались на выставках и были опубликованы в каталогах этих выставок. Предметы из 1-го Филипповского кургана, не экспонировавшиеся на выставках, также в большинстве своем изданы по материалам отчетов и описей находок экспедиции А.Х. Пшеничнюка [Пшеничнюк, 2013]. Недавно вышел в свет каталог предметов из Филипповки, хранящихся в Музее археологии и этнографии в Уфе [Коллекции ..., 2018], в котором эскпонировавшиеся на выставках предметы объединены с ранее не выставлявшимися.

Стилистические особенности произведений звериного стиля из Филипповки послужили темой для целого ряда специальных исследований. Кроме того, эти предметы весьма информативны, поэтому их часто упоминают в работах, посвященных различным проблемам истории ранних кочевников. Обращаться к литературе, затрагивающей произведения искусства из Филипповских курганов, мы будем по мере работы с конкретными предметами, поскольку они весьма разнообразны.

Среди находок 2013 г. есть вещи, практически полностью аналогичные найденным ранее в этом кургане, а также более или менее сходные с ними, но имеются и предметы уникальные. Начнем с вещей и изображений, похожих на известные ранее.
В погребении 2 найдены две золотые оковки сосудов с зооморфными ручками. Одна из ручек выполнена в форме хищного зверя, стоящего на четырех лапах с опущенной головой (рис. 1,1), Л.Т. Яблонский определяет его как медведя [Яблонский, 2014a, с. 5]. Подобные ручки, хоть и отличающиеся от нашей в некоторых деталях, найдены в 1-м Филипповском кургане в тайнике 1 (рис. 1,2-4). Среди этих находок к нашей ближе всего фигуры зверей с гладкой поверхностью (рис. 1,2,3) [Пшеничнюк, 2012, с. 244. рис. 2,6,7], сердцевидными ушами, небольшими глазами со слезницей. Когти на всех рассматриваемых фигурках показаны по-разному. Различаются изображения и по трактовке зубастой пасти, лопатки и бедра, некоторым нюансам поз хищника. Отличается новая находка и декором оковки: вместо привычной для этого комплекса витиеватой зооморфной композиции здесь нанесен геометрический орнамент.

Другая золотая оковка [Яблонский, 2014в, с. 25-26; 2014г, рис. 77-78] снабжена ручкой в виде копытного, по определению Л.Т. Яблонского - «кулана или самки (безрогой) джейрана» [Яблонский, 2016, с. 746]. Ручки в виде фигурок копытных в такой позе встречаются, хотя и реже, в материалах кургана [The Golden Deer ... , 2000, cat. 75; Пшеничнюк, 2012, с. 244 , рис. $2,1,2$; Коллекции ... , 2018 , кат. 458, 466]. Оковки этого сосуда оформлены в зверином стиле, на одной из них изображены головы оленей, обращенные друг к другу. На другой оковке вокруг отверстия для ручки расположены задние ноги копытного животного - прием, распространенный в оформлении сосудов этого кургана [Королькова, 2018 , с. 32-33; Пшеничнюк, 2012, с. 214-215, рис. 157,158 , с. 223 , рис. 169]. Стиль изображения на указанных оковках вполне вписывается в картину стилистического разнообразия изображений на подобных предметах из кургана. Сосуд был закрыт крышкой из рога лося [Яблонский, 2014a, с. 6; 2014г, рис. 75-76]. Ручка крышки была оформлена в виде головы хищной птицы, по контурам сходная с рядом изображений птичьих голов из Филипповки.

Пальцы рук погребенной были унизаны перстнями: по перстню на каждом пальце. Все они практически одинаковы: на щитке помещено изображение оленя с подогнутыми но- 
гами (рис. 2,1). Рога трактованы в виде ветви, расположенной над спиной животного, отростки которой трансформированы в головы хищных птиц; всего три отростка. Морда оленя длинная, горбоносая, что вообще характерно для изображений из Филипповки. Не вполне обычна поза животного: подогнутые ноги не лежат одна на другой, как это принято для изображений копытных в скифском зверином стиле, а передняя нога вытянута вперед, при этом обе ноги согнуты (то есть подогнуты копыта). Оленей в подобной позе встречаем в материалах нашего же кургана: на нашивных бляшках (рис. 2,2), а также на некоторых золотых оковках деревянных сосудов (рис. 2,3-6). Заметим, что такое отклонение от правил скифского звериного стиля можно считать особенностью звериного стиля Филипповки.

На серии золотых нашивных бляшек представлена фигура сайгака (рис. $3,1,3$ ). Л.Т. Яблонский называет его «свернутым в кольцо» [Яблонский, 2014a, с. 6], однако с этим трудно согласиться. Дело даже не в том, что упомянутая поза свойственна изображениям не копытных, а хищных зверей - как мы только что убедились, в материале Филипповки встречаются отклонения от канонов скифского звериного стиля. Сайгак на этих бляшках лежит, подогнув передние и задние копыта - как на изображениях оленей, описанных выше. Голова животного повернута назад и занимает в композиции центральное место. В скифском зверином стиле V-IV вв. до н.э. встречаются композиционно похожие изображения (например, фигурки оленей из Семибратних курганов в Прикубанье [Артамонов, 1966, табл. 128, 130]), а в материалах 1-го Филипповского кургана с повернутой назад головой изображен олень в сцене терзания на золотой оковке сосуда из тайника 1 (рис. 2,5). Однако у сайгака на бляшке показана и вторая передняя нога: она проходит по краю бляшки от лопатки параллельно туловищу животного, то есть закинута вверх. Нижняя часть другой задней ноги с копытом видна между ухом и шеей, копыто читается на фоне шеи. Похоже, перед нами смелая попытка выйти за рамки канонов звериного стиля и передать некую сложную позу в некоем ракурсе. Пока мы не нашли чего-либо подобного ни в материалах
Филипповки, ни где-либо еще и не можем даже предположить, какая именно поза отражена столь сложным и непонятным образом. При этом некоторые особенности композиции изображения на бляшке продиктованы ее контуром, приближающимся к кругу, - этим, думается, можно объяснить и некоторое сходство с изображениями свернувшегося зверя. Что же касается трактовки деталей: глаз со слезницей, оформление контуров рта, фигуры на лопатке и бедре животного, - то они находят множество аналогий в том же 1-м Филипповском кургане. Бляшки похожи на предметы этой категории из этого же кургана и по характеру рельефа поверхности (рис. 2,2) [The Golden Deer ..., 2000, cat. 100; Коллекции ... , 2018, кат. 721-784].

Бляшки со сценой терзания (рис. $3,2,4$ ) имеются в двух вариантах: ориентированные либо влево, либо вправо. Изображения на них практически идентичны, различия крайне незначительны. Хищный зверь нападает на сайгака сверху и сзади: его туловище расположено над спиной копытного, ухо которого находится в пасти хищника. У хищника лапы с большими когтями: задние показаны в шаге, одна из них, слегка согнутая, находится над крупом сайгака, другая ниже, за пределами туловища копытного. Между лапами показан длинный хвост со спирально закрученным кончиком. Когти передней лапы находятся в области холки сайгака. Возможно, мы видим когти другой передней лапы в районе ребер сайгака - в таком случае получается, что хищник обхватил жертву поперек туловища. Не исключено, впрочем, что рельефными полосками показаны не когти зверя, а ребра сайгака - прямых аналогий ни такому варианту сцен терзания, ни такой трактовке ребер мы пока не знаем. Еще одно отступление от профильного изображения состоит в следующем: мы наблюдаем два (а не один) рога у сайгака, две его передние ноги. Что касается его задних ног, то, возможно, другая нога, находящаяся на заднем плане, вытянута и проходит по низу бляшки, в углу ее помещено копыто. При этом копыто изображено так, что невозможно не видеть в нем голову рогатого животного (кружок в центре преувеличен, треугольная часть сильно вытянута и направлена вверх). Подобные нарушения традиции стро- 
го профильного изображения в материалах кургана мы наблюдаем только на описанной выше бляшке с фигурой сайгака. Сцены терзания в 1-м Филипповском кургане помещены на зооморфных ручках, реже - на оковках сосудов, но примеров полной композиционной аналогии сценам на бляшках (хищник сверху нападает на сайгака и держит в пасти его ухо) мы не видим. Как правило, в пасти хищника помещено не ухо, а морда жертвы, при этом во всех сравниваемых случаях ухо или морда помещаются в пасти зверя весьма компактно (рис. 2,3,5, 5,3) [The Golden Deer ..., 2000, cat. 26, 83; Коллекции ... , 2018, кат. 488].

Голова хищника округлая, подобная голове зверя в сцене терзания на ручке сосуда (рис. 2,3). Сходны и контуры раскрытой пасти зверя, а также спиральный завиток уха. Кстати, на нашей бляшке завиток уха по размерам и контурам спирали подобен завитку кончика хвоста, но спирали направлены в противоположные стороны.

Любопытно сочетание круглой головы зверя с рельефной полосой, проходящей по краю его лопатки и образующей треугольную фигуру на спине. Подобный элемент встречаем на фигурах зверей, оформляющих зооморфные ручки сосудов из кургана (рис. 1,2-4), но здесь он сочетается с удлиненными мордами животных. Такое сочетание встречается довольно широко в разных вариантах скифского звериного стиля, при этом вид изображенного животного, как правило, трудно определить [Переводчикова, 2017, с. 107].

Что касается трактовки поверхности предмета, то в этом отношении рассмотренные бляшки вполне сходны с другими предметами данной категории, происходящими из кургана.

Итак, вещи разных категорий обнаруживают стилистическую близость к ранее известным предметам из кургана. Интересно, что мы не нашли полных аналогий ни одному из предметов, а признаки сходства всегда обнаруживаются между вещами не только разных категорий, но и не тождественными по стилю исполнения. Это обстоятельство убеждает нас в возможности дальнейших поисков подобных параллелей.

Переходим теперь к одежде погребенной, на рукавах которой, как уже было сказано выше, обнаружены фигуры оленей (рис. 4,1,2).
В процессе работы с объектом стало понятно, что на данном предмете одежды находилось около десяти протом оленей, изображенных идущими вправо, вереницей друг за другом, представляя собой, таким образом, не сюжетную композицию, а ритмический рисунок. Точно такой же рисунок, только выполненный зеркально, вне всяких сомнений, находился и на рукаве у левой руки, однако перемещенное состояние большинства бусин позволяет разглядеть лишь изнанку одной протомы оленя посередине рукава и отдельные детали прочих фигур.

Поскольку правый рукав сохранился лучше, вся исследовательская работа сосредоточилась на нем. Практически не потревожен рисунок двух фигур. Они выполнены при помощи одинаковых приемов вышивания - ряд к ряду, повторяя изгибы тела. Вероятно, в первую очередь вышивались фигуры оленей, в основном мелкими золотыми бусинами, затем фигура обшивалась каймой голубого бисера, а затем им же заполнялись промежутки между фигурами.

В поисках сходства вышитых фигур оленей с изображениями на предметах других категорий из 1-го Филипповского кургана следует, наверное, остановиться на некоторых признаках, уже известных в качестве общих для разных групп изображений оленей из кургана.

О сходстве стилей деревянных скульптур оленей и изображений на золотых оковках писала Е.Ф. Королькова, отмечая, что они сближаются «орнаментальностью декора, статичностью фигуры, а также трактовкой деталей и пропорциями» [Королькова, 2006, c. 43 , табл. 2,2-4,12].

Описывая стилистическое сходство этих групп вещей, А.Х. Пшеничнюк отметил, что и для скульптур оленей, и для их изображения на оковках сосудов характерны длинные горбоносые морды [Пшеничнюк, 2006, с. 32].

К признакам сходства скульптур оленей с изображениями на оковках сосудов относится также трактовка глаза несколькими штрихами, создающими угловатую форму (при этом глаз выглядит подрисованным с двух сторон). На туловище животных в обеих группах изображений встречаются похожие орнаментальные мотивы, использованные, в том числе, и для выделения зоны ребер и акцен- 
тирования лопатки и бедра [Переводчикова, 2016б, с. 220-221].

У вышитых бисером оленей (рис. 5,1,2), несмотря на то что у этой техники совсем иные возможности передачи нюансов изображения, можно все же проследить некоторые из отмеченных признаков. Это длинные подпрямоугольные головы, местами они выглядят как горбоносые, местами можно разглядеть окаймленный валиком рот, четко читается подтреугольный глаз.

Отростки рогов у вышитых оленей показаны в виде спиралей - по форме спиралей они более всего похожи на рога оленя на уже упомянутой золотой бляшке (рис. 2,2), хотя разнообразные композиции из спиралей обычны как для оковок, так и для скульптур оленей (рис. 5,3-6).

Четко прослеживается «бородка», которую можно встретить на некоторых изображениях на оковках (рис. 5,4) [The Golden Deer ... , 2000, cat. 26], на уже упомянутой 30оморфной ручке сосуда [The Golden Deer ..., 2000, cat. 75; Коллекции ... , 2018, кат. 458] и почти на всех скульптурах.

У всех оленей на рукавах погребенной прослеживается выдвинутая вперед нога - этот признак наблюдаем и на целом ряде оковок (рис. 5,3) [The Golden Deer ... , 2000, cat. 26, 27, $34,39,45]$.

Перечисленные признаки достаточно убедительно свидетельствуют о стилистическом родстве рассмотренных групп изображений. Вышитые бисером фигуры оленей, несмотря на особенности техники их выполнения, прекрасно вписываются в общую картину звериного стиля Филипповки. Иными словами, рукава расшиты не просто оленями, а «филипповскими оленями». Наш вывод дополняет наблюдения O.В. Аникеевой о наличии в реконструируемом костюме элементов скифского звериного стиля [Аникеева, Яблонский, 2019 , с. 21]. Не вдаваясь в подробности реконструкции костюма, заметим, что при ее интерпретации имеет смысл учитывать специфически «филипповский» характер произведений звериного стиля.

Итак, находки 2013 г. по своим признакам вписываются в общую картину звериного стиля кургана 1 курганного могильника Филипповка 1. Мы подробно разобрали при- знаки всех опубликованных находок. Неопубликованные материалы не противоречат этому выводу.

Среди находок 2013 г. присутствует серия предметов ахеменидского производства. Л.Т. Яблонский успел составить каталог этих вещей [Яблонский, 2016, с. 748-763] и на основе их анализа пришел к выводу: «Технологические приемы изготовления предметов и особенности их орнаментики не исключают допущения, что они были изготовлены в каких-то ювелирных мастерских, расположенных на территории державы Ахеменидов» [Яблонский, 2016, с. 763]. Изучение техники изготовления вещей, проведенное уже в последующие годы [Аникеева и др., 2017, с. 68], привело исследователей к более уверенному заключению, что предметы «были изготовлены в ремесленном центре Ахеменидского Ирана» [Аникеева и др., 2018, с. 214]. В этой группе находок нас интересуют предметы, в состав которых входят изображения в зверином стиле.

Серебряное зеркало с плакированной золотом ручкой (рис. 7,1 ) и изображениями на диске включено Л.Т. Яблонским в каталог вещей ахеменидского производства [Яблонский, 2016, с. 750, рис. 4]. Композиция из рельефных позолоченных фигур выполнена в переднеазиатской традиции: таковы фигура орла в центре диска, шествующие вокруг него крылатые быки и расположенные во внешнем круге лотосовидные пальметки. Сильный контраст этим изображениям являет ручка зеркала, о которой исследователь справедливо пишет, что она оформлена в скифском зверином стиле [Яблонский, 2014a, с. 5]. На верхнем и нижнем концах ручки помещены фигуры оленей с перевернутым на $180^{\circ}$ туловищем. Передняя и задняя ноги оформляют края ручки. Голова животного повернута назад. На лопатке и бедре помещены рельефные каплевидные углубления. Вдоль шеи проходят две рельефные полоски, особенно четко видные на верхней фигуре. Удлиненные головы не сужаются к концу, а слегка расширяются, на них рельефными штрихами показаны ноздря и рот животного. Маленький круглый глаз помещен в большое подтреугольное углубление. Рога оленя на верхнем конце ручки выглядят как подпря- 
моугольной формы корона из спиралевидных завитков, которая частично заходит на поверхность диска зеркала. Рога оленя на нижнем конце ручки начинаются как спирали и переходят в композицию из спиралевидных фигур, напоминающих стилизованные птичьи головы. Эта ажурная композиция и составляет тело ручки и доходит до верхней фигуры оленя. Завершается она четырьмя спиралевидными завитками, касающимися туловища оленя, расположенного на верхнем конце ручки.

Нетрудно заметить, что в описании оленей участвуют уже неоднократно упомянутые в этой статье признаки: подтреугольный глаз, вытянутая морда, каплевидные фигуры на лопатке и бедре. Нами еще не упоминалось перевернутое туловище, но изображения животных в такой позе встречаются на оковках сосудов из 1-го Филипповского кургана (рис. 7,2-5). Не упоминали мы прежде и параллельные полоски на шее оленей, в то время как они являются одной из характерных черт изображений на богато орнаментированных оковках сосудов [Переводчикова, 2016a, с. 24] (например: рис. 7,6). Что касается формы рогов оленей, то у верхнего она очень напоминает верхнюю часть «лировидных» ${ }^{2}$ рогов скульптурных оленей (рис. $7,7,8$ ). Рога нижнего оленя тоже основаны на этой форме, но здесь она по необходимости растянута на нужную длину.

Такой контраст между изображениями на диске и на ручке удивителен. При этом ни в одном из описаний зеркала нет ни намека на переделку, ремонт предмета и что-либо подобное. Иными словами, перед нами вещь, сделанная в мастерских Ахеменидского Ирана, но при этом несущая на себе изображения в зверином стиле, характерном именно для Филипповки. Единственное объяснение этому сочетанию обстоятельств - зеркало сделано ахеменидскими мастерами по заказу кочевников, оставивших Филипповские курганы.

Примеры подобного явления представляют собой височные подвески (рис. 6,1-3)изделия, выполненные в сложной ювелирной технике, несомненно - мастерами Ахеменидского Ирана [Аникеева и др., 2018, с. 214], но при этом среди деталей указанных предме- тов наблюдаем головы верблюдов, исполненные именно подобно тем, какие мы видим в материалах 1-го Филипповского кургана (рис. 6,4-6).

Не исключено, что при работе над головой быка на цилиндрическом элементе подвески № 2 (рис. 6,2) ахеменидский мастер также вдохновлялся филипповскими оленями. На такие мысли наводит вид рогов, которые совсем не похожи ни на бычьи, ни даже на буйволиные- они выполнены в виде тонких длинных спиралей.

Таким образом, раскопки 2013 г. принесли принципиально новую для 1-го Филипповского кургана категорию находок. Если до этого в материале памятника были известны ахеменидские импортные вещи, а также предметы, сделанные под влиянием ахеменидского искусства, то теперь мы знаем и изделия, изготовленные ахеменидскими мастерами по заказу кочевников, оставивших курган. Это обстоятельство, впрочем, не должно нас сильно удивлять, поскольку в материале кургана уже были выявлены примеры подобной работы китайских мастеров, изготовивших некоторые золотые оковки [Переводчикова, 2012, с. 96-100; 2016a, с. 30-32].

Подводя итоги нашей работы, заметим, что новые находки не только вписались в контекст звериного стиля кургана 1 могильника Филипповка 1, но сделанные в процессе работы наблюдения еще раз подтвердили мысль А.Х. Пшеничнюка, что комплекс кургана «является не набором случайных предметов, собранных, как полагают некоторые исследователи, путем обмена и торговли с южными цивилизациями или же в результате военных набегов, а представляет собой единое целое» [Пшеничнюк, 2006, с . 32].

\section{ПРИМЕЧАНИЯ}

${ }^{1}$ Новое название было предложено Л.Т. Яблонским [Яблонский, 2014a, с. 4] и с тех пор считается принятым. Однако, поскольку старое название уже успело к тому времени войти в литературу, мы признаем и за ним право на существование.

2 Термин предложен Е.Е. Нечвалода в докладе на X конференции «Проблемы сарматской археологии и истории» в г. Севастополь в сентябре 2019 г. Доклад не опубликован. 

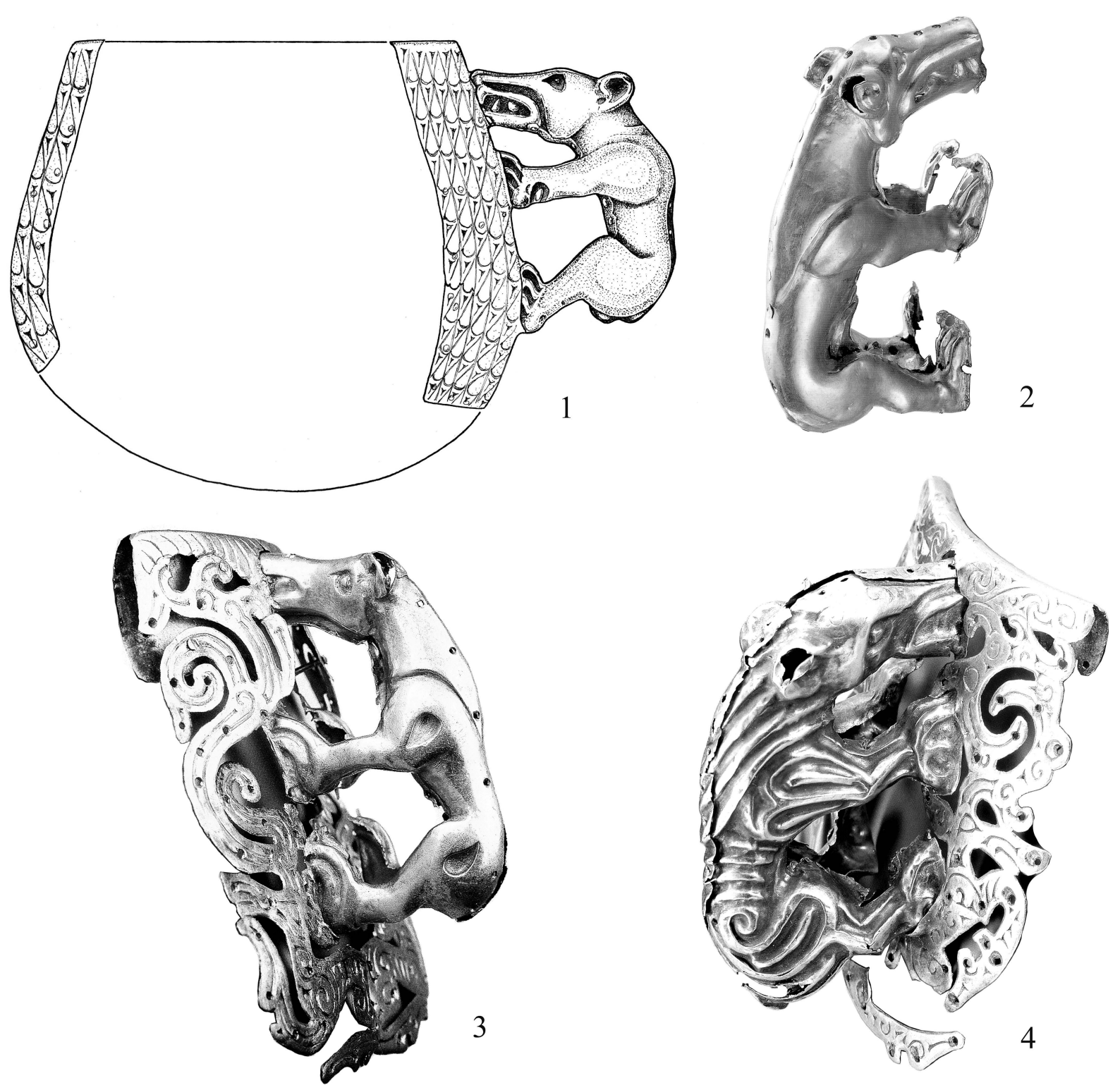

Рис. 1. Зооморфные ручки сосудов:

1 - Филипповка 1, курган 1, погребение 2 (рис. К.С. Окорокова);

2-4 - Филипповка 1, курган 1, тайник 1 (по: [The Golden Deer ..., 2000: 2 - cat. 74, 3 - cat. 73, 4 - cat. 77])

Fig. 1. Zoomorphic handles of vessels:

1 - Filippovka 1, kurgan 1, burial 2 (drawing by K.S. Okorokov);

2-4 - Filippovka 1, kurgan 1, treasure pit 1 (after: [The Golden Deer ..., 2000: 2 - cat. 74, 3- cat. 73, 4 - cat. 77]]) 

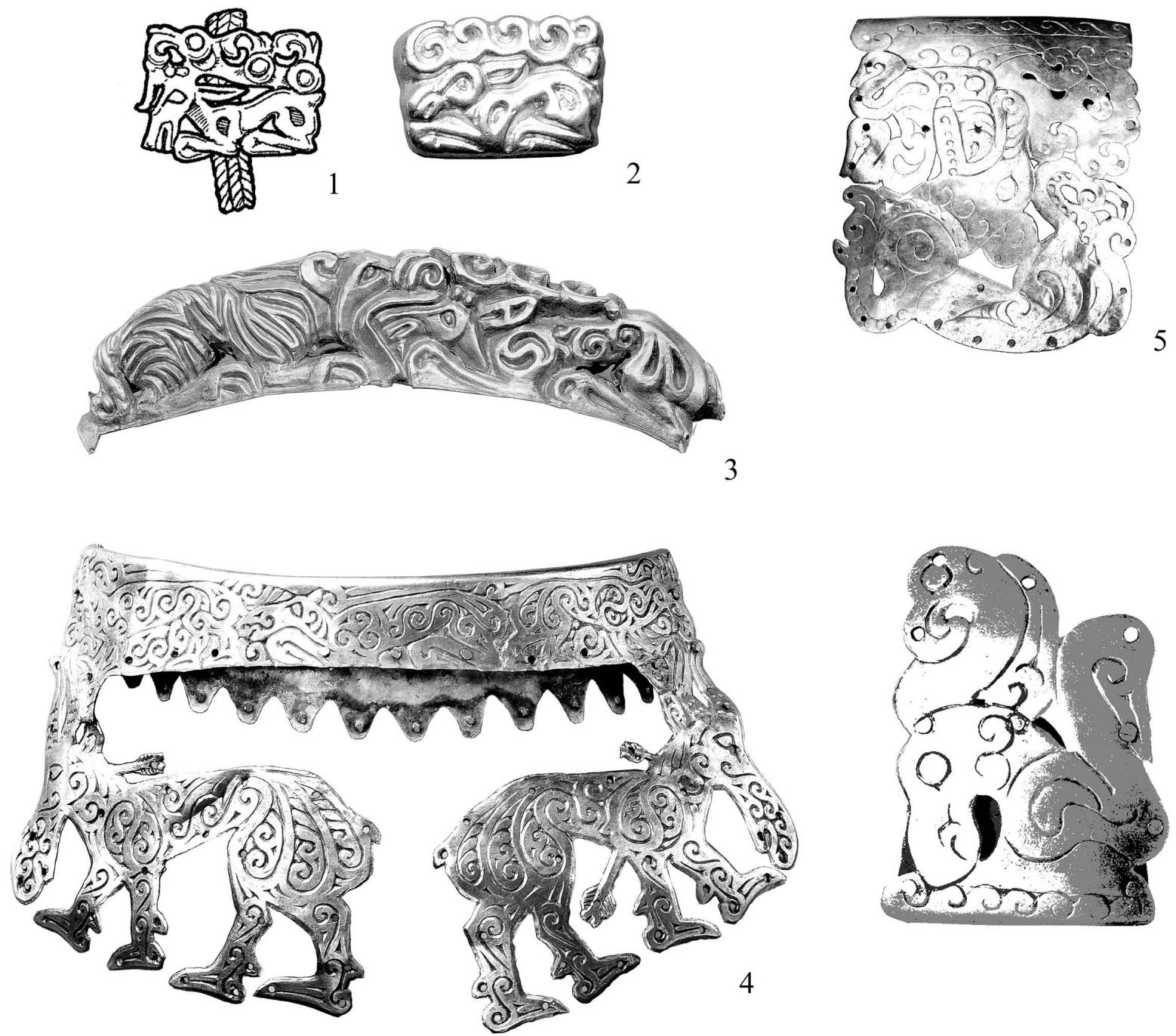

Рис. 2. Перстни и некоторые стилистические параллели:

1 - перстень, Филипповка 1, курган 1, погребение 2 (рис. К.С. Окорокова);

2 - нашивная бляшка, Филипповка 1, курган 1, тайник 2 (по: [The Golden Deer ..., 2000, cat. 99]; 3-6 - оковки сосудов, Филипповка 1 , курган 1 , тайник 1

(по: [The Golden Deer ..., 2000: 3,4 - cat. 24, 5 - cat. 64, 6 - cat. 41])

Fig. 2. Finger rings and some stylistic parallels:

1 - ring, Filippovka 1, kurgan 1, burial 2 (drawing by K.S. Okorokov);

2 - plague for dress, Filippovka 1, kurgan 1, treasure pit 2 (after: [The Golden Deer ..., 2000, cat. 99]);

3-6 - plagues for vessels, Filippovka 1, kurgan 1, treasure pit 1

(after: [The Golden Deer ..., 2000: 3,4 - cat. 24, 5 - cat. 64, 6- cat. 41]) 

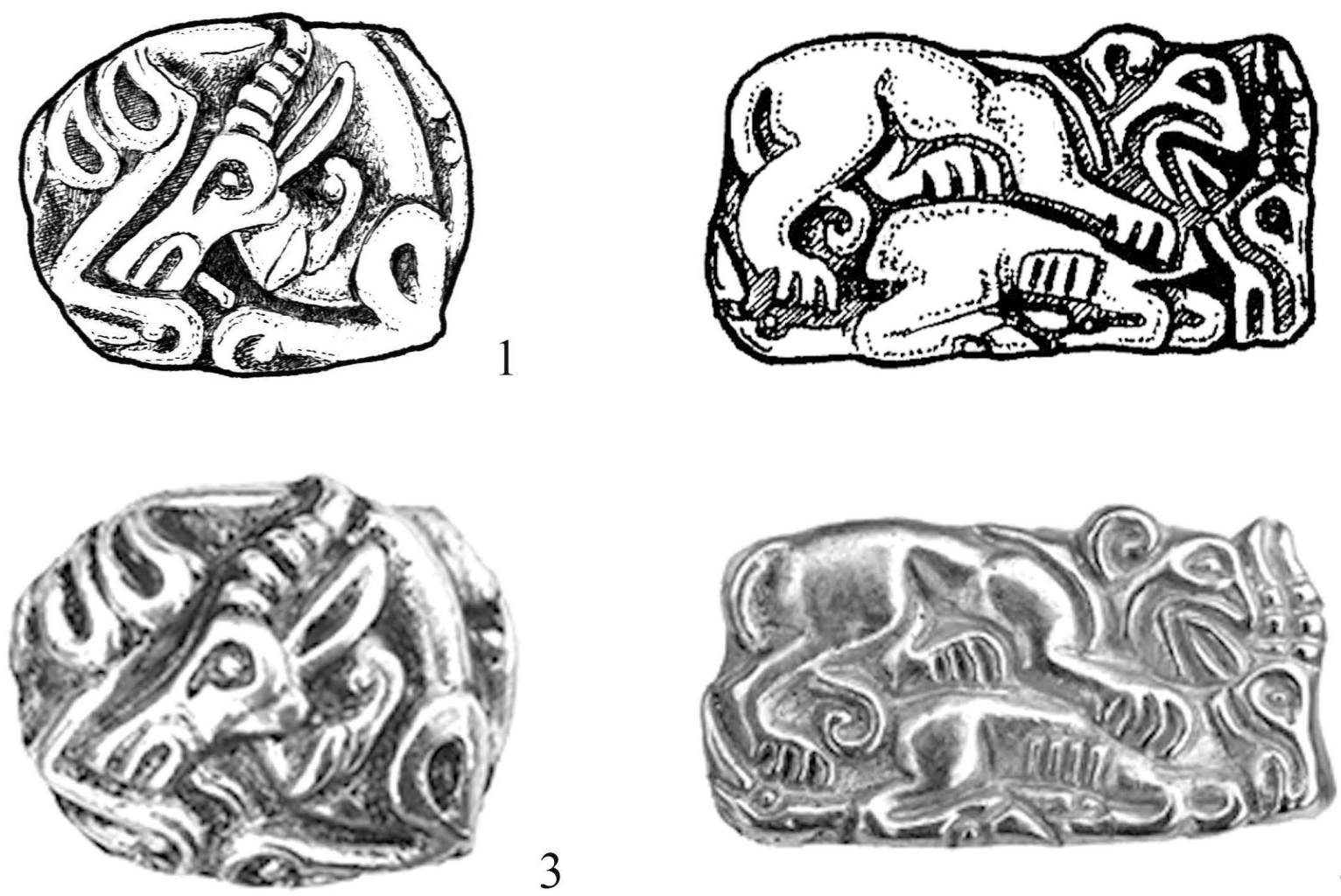

3

Рис. 3. Золотые нашивные бляшки:

1 - бляшка с фигурой сайгака, прорисовка (по: [Аникеева, Яблонский, 2019, с. 18, рис. 2,7]); 2 - бляшка со сценой терзания, прорисовка (по: [Аникеева, Яблонский, 2019, с. 18, рис. 2,8]); 3 - бляшка с фигурой сайгака (по: [Яблонский, 2014a, рис. III,3]); 4 - бляшка со сценой терзания (по: [Яблонский, 2014a, рис. III,1])

Fig. 3. Golden plagues:

1 - plague with sajga figure, drawing (after: [Anikeeva, Yablonsky, 2019, p. 18, fig. 2,7]); 2 - plague with a torment scene, drawing (after: [Anikeeva, Yablonsky, 2019, p. 18, fig. 2,8]); 3 - plague with sajga figure (after: [Yablonsky, 2014a, fig. III,3]); 4 - plague with a torment scene (after: [Yablonsky, 2014a, fig. III,1]). 
K.S. Okorokov, E.V. Perevodchikova. The 2013 Finds in the Context of the Animal Style
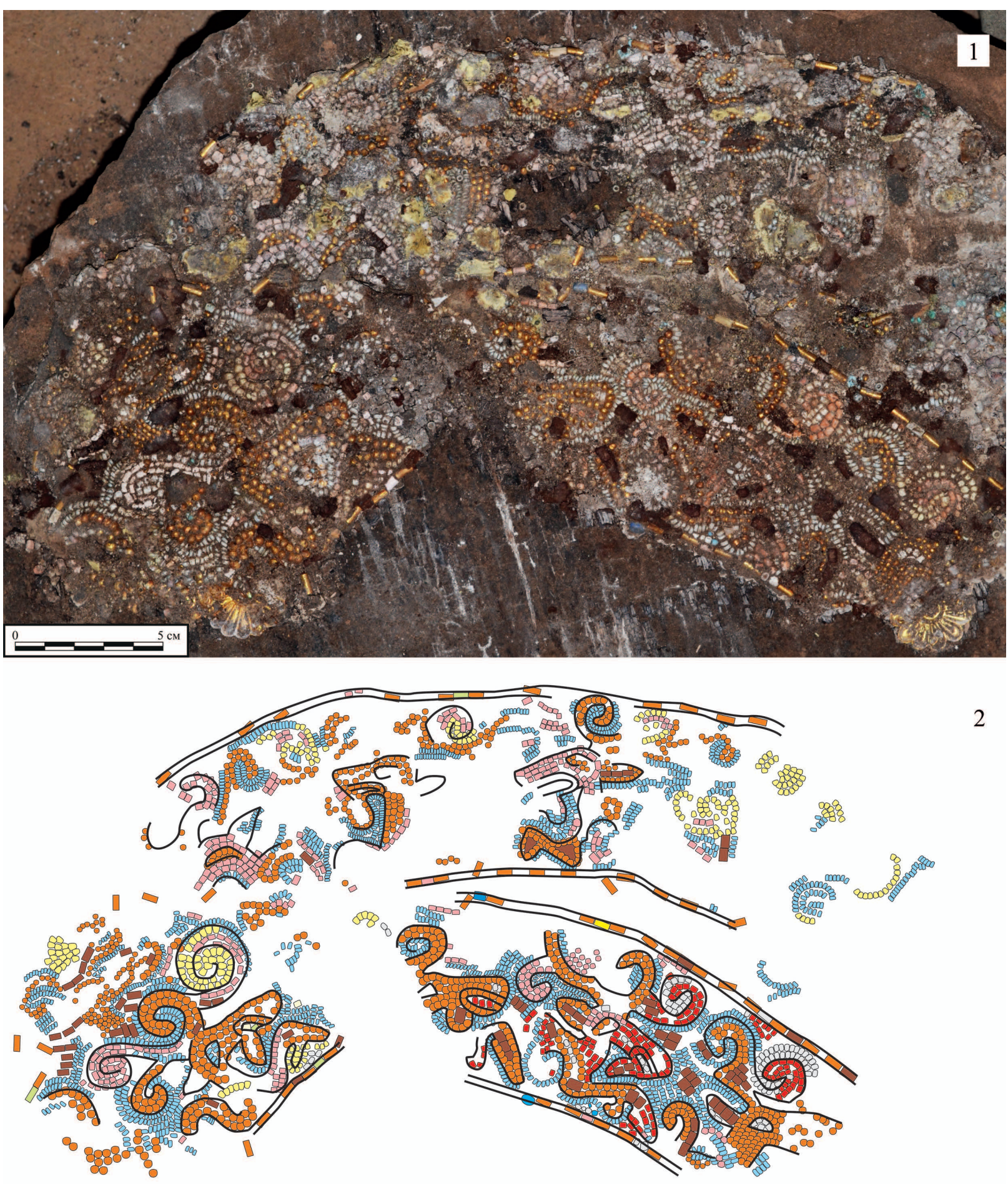

Рис. 4. Деталь одежды, расшитая бисером:

1 - фотография; 2 - графическая реконструкция К.С. Окорокова

Fig. 4. Fragment of a dress embroidered with beads:

1 - photo; 2 - graphic reconstruction by K.S. Okorokov 

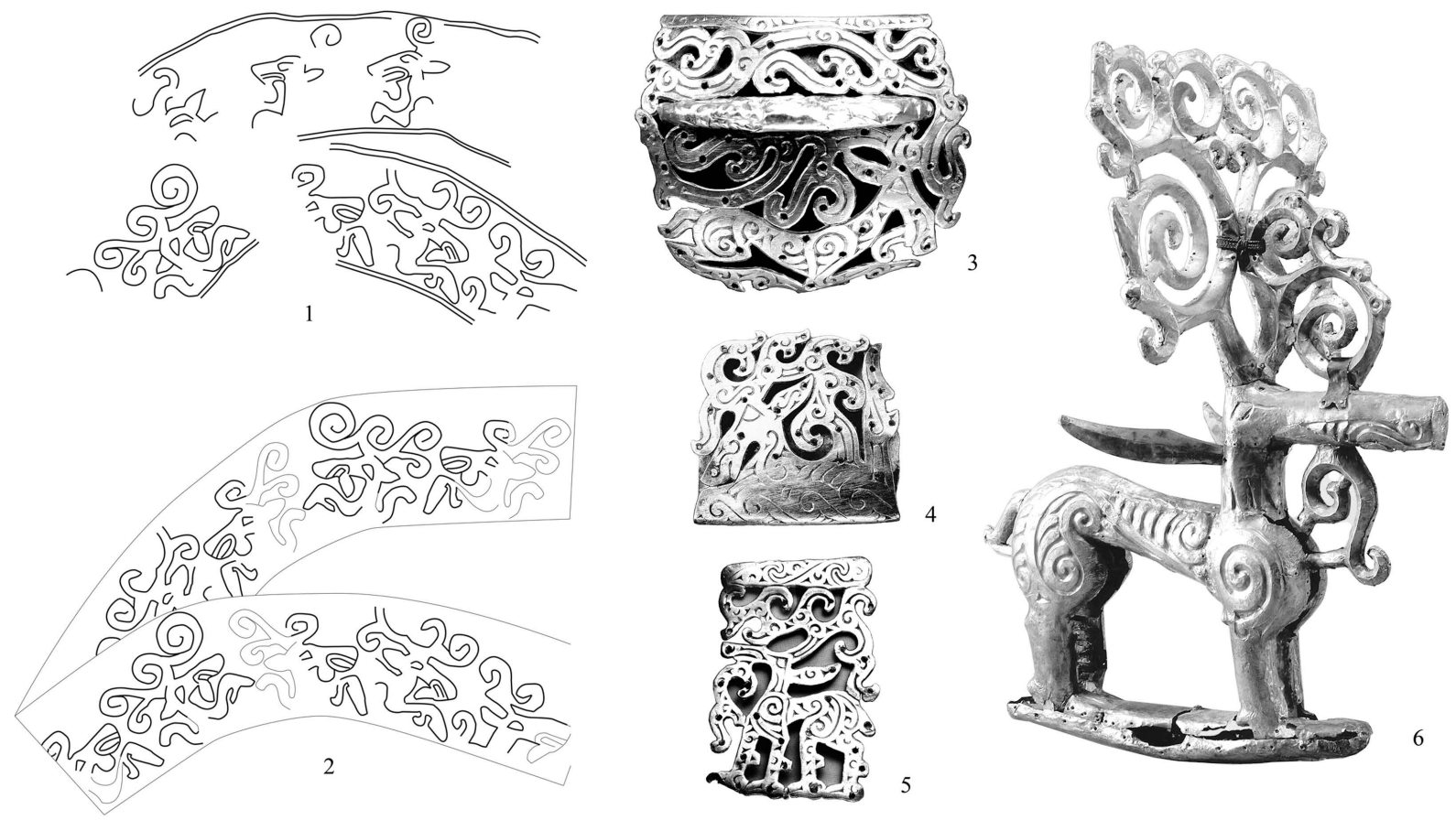

Рис. 5. Деталь одежды, расшитая бисером, и некоторые стилистические параллели:

$$
1-2 \text { - графическая реконструкция К.С. Окорокова; }
$$

3-5 - оковки сосудов, Филипповка 1, курган 1, тайник 1 (по: [The Golden Deer ..., 2000: 3 - cat. 25, 4 - cat. 38, 5 - cat. 28]); 6 - скульптура оленя, Филипповка 1, курган 1, дромос (по: [The Golden Deer ..., 2000, cat. 2])

Fig. 5. Fragment of a dress embroidered with beads and some stylistic parallels:

$$
1-2 \text { - graphic reconstruction by K.S. Okorokov; }
$$

3-5 - plagues for vessels, Filippovka 1, kurgan 1, treasure pit 1 (after: [The Golden Deer ..., 2000: 3 - cat. 25, 4- cat. 38, 5 - cat. 28]); 6 - figure of a stag, Filippovka 1, kurgan 1, entryway to the burial (after: [The Golden Deer ..., 2000, cat. 2]) 

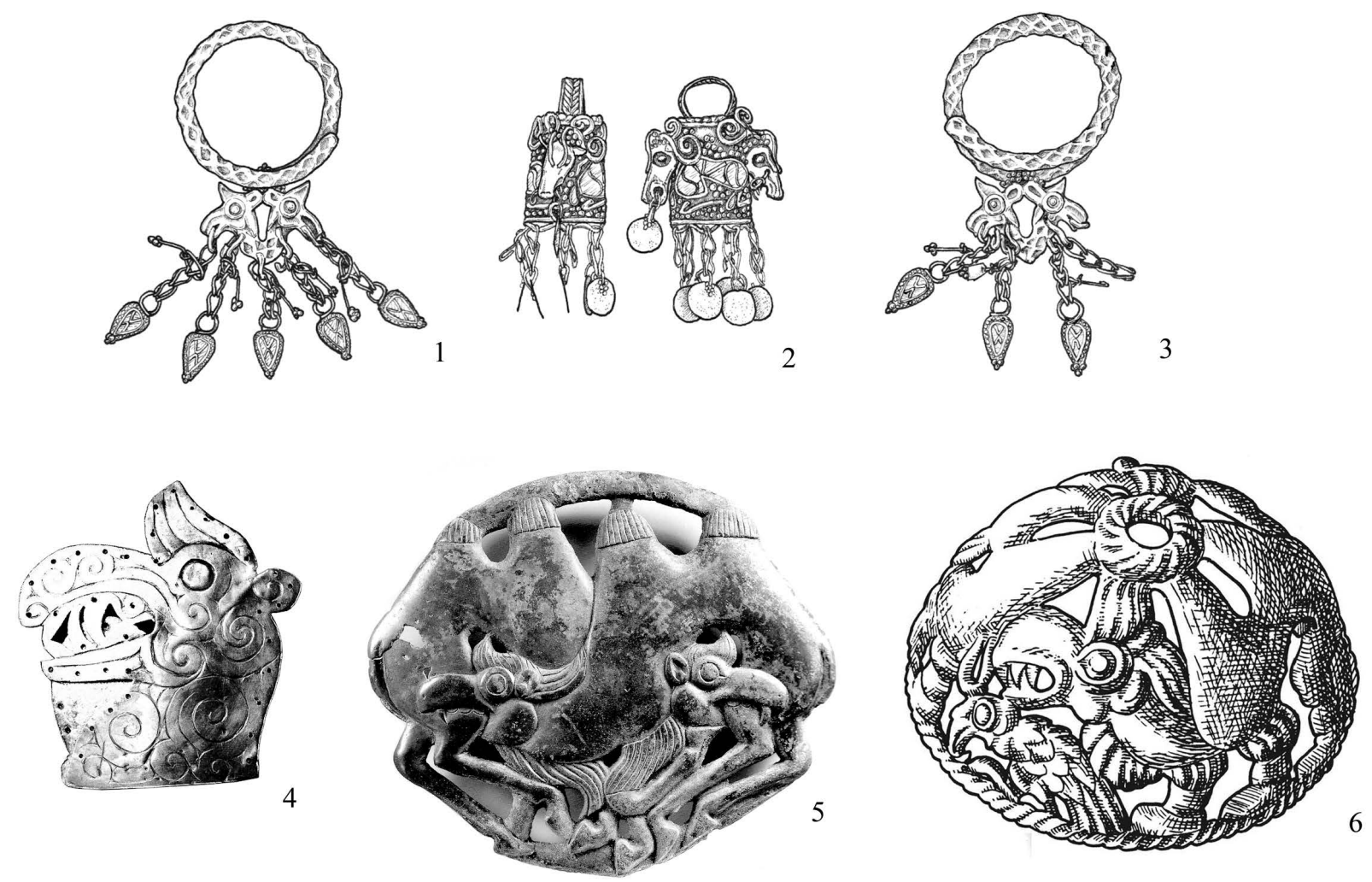

Рис. 6. Височные подвески и некоторые стилистические параллели:

1-3 - Филипповка 1, курган 1, погребение 2, височные подвески (по: [Яблонский, 2014б, с. 197, рис. 2]); 4 - оковка сосуда, Филипповка 1, курган 1, тайник 1 (по: [The Golden Deer ..., 2000, cat. 67]; 5 - уздечная бляха, Филипповка 1, курган 1, дромос (по: [The Golden Deer ..., 2000, cat. 13]; 6 - украшение щита или горита (?), Филипповка 1, курган 1, тайник 2 (по: [Пшеничнюк, 2012, с. 110, рис. 23,2])

Fig. 6. Pendants and some stylistic parallels:

1-3 - Filippovka 1, kurgan 1, burial 2 (after: [Yablonsky, 2014b, p. 197, fig. 2]);

4 - plague for a vessel, Filippovka 1, kurgan 1, treasure pit 1 (after: [The Golden Deer ..., 2000, cat. 67]);

5 - phalera, Filippovka 1, kurgan 1, entryway to the burial (after: [The Golden Deer ..., 2000, cat. 13]);

6 - shield or quiver ornament (?), Filippovka 1, kurgan 1, treasure pit 2 (after: [ Pshenichnyuk, 2012, p. 110, fig. 23,2]) 

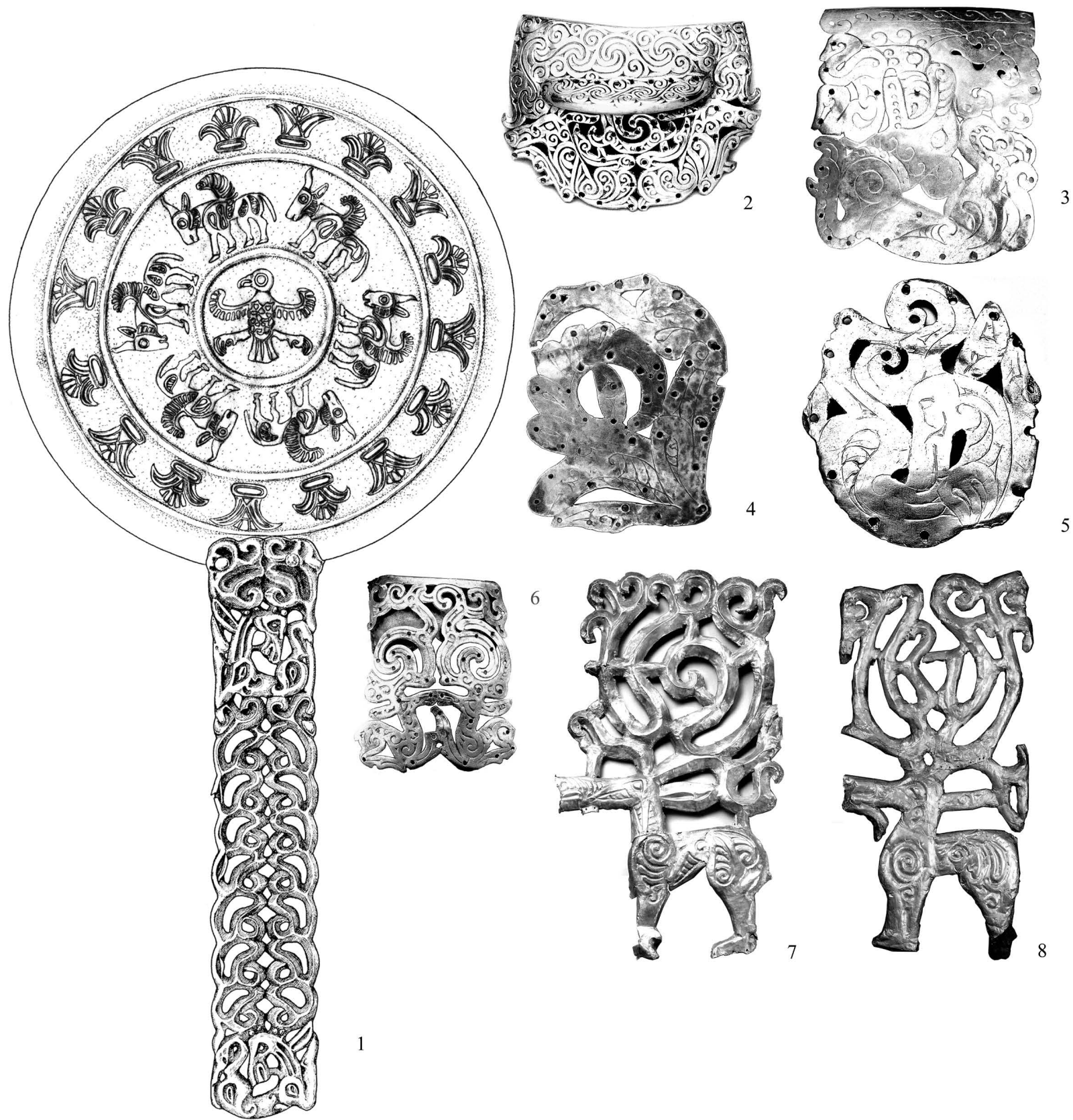

Рис. 7. Зеркало и некоторые стилистические параллели:

1 - Филипповка 1, курган 1, погребение 2 (по: [Яблонский, 2014б, с. 196, рис. 1]); 2-6 - оковки сосудов, Филипповка 1 , курган 1 , тайник 1

(по: [The Golden Deer ..., 2000: 2 - cat. 27, 3 - cat. 64, 4 - cat. 45, 5 - cat. 44, 6 - cat. 34]);

7 - скульптура оленя, Филипповка 1, курган 1, тайник 1 (по: [The Golden Deer ..., 2000, cat. 21);

8 - скульптура оленя, Филипповка 1, курган 1, тайник 2 (по: [Золотые олени ..., 2001, кат. 103])

Fig. 7. Mirror and some stylistic parallels:

1 - Filippovka 1, kurgan 1, burial 2 [Yablonsky, 2014b, p. 196, fig. 1];

2-6 - plagues for vessels, Filippovka 1, kurgan 1, treasure pit 1

(after: [The Golden Deer ... , 2000: 2 - cat. 27, 3 - cat. 64, 4 - cat. 45, 5 - cat. 44, 6 - cat. 34]);

7 - figure of a stag, Filippovka 1, kurgan 1, treasure pit 1 (after: [The Golden Deer ..., 2000, cat. 21]);

8 - figure of a stag, Filippovka 1, kurgan 1, treasure pit 2 (after: [Zolotye oleni ..., 2001, cat. 103]) 


\section{СПИСОК ЛИТЕРАТУРЫ}

Аникеева О. В., Шемаханская М. С., Яблонский Л. Т., 2017. Ювелирные шедевры ахеменидской эпохи из гробницы знатной женщины в Южном Приуралье // Ювелирное искусство и материальная культура. СПб. : Эрмитаж. С. 5-11.

Аникеева О. В., Нацкий М. В., Шемаханская М. С., Яблонский Л. Т., 2018. Ювелирные украшения из погребения знатной женщины (могильник Филипповка 1, курган 1, погребение 2) // Духовная модернизация и археологическое наследие : материалы Междунар. науч.-практ. конф. «Маргулановские чтения -2018». Алматы ; Актобе : Институг археологии им. А.Х. Маргулана. С. 211-219.

Аникеева О. В., Яблонский Л. Т., 2018. Кустарное ремесло у ранних кочевников Южного Урала // ХХІ Уральское археологическое совещание, посвященное 85 -летию со дня рождения Г.И. Матвеевой и 70 -летию со дня рождения И.Б. Васильева : материалы Всерос. науч. конф. с междунар. участием. Самара : Изд-во СГСПУ. С. $189-193$.

Аникеева О. В., Яблонский Л. Т., 2019. Материалы к реконструкции женского погребального костюма из элитного захоронения ранних кочевников Южного Приуралья // Крым в сарматскую эпоху (II в. до н.э. - IV в. н.э.) : материалы X Междунар. науч. конф. «Проблемы сарматской археологии и истории». Симферополь : ООО «Фирма «Салта» ЛТД». С. 14-24.

Артамонов М. И., 1966. Сокровища скифских курганов в собрании Государственного Эрмитажа. Прага ; Л. : Артия : Советский художник. 306 с.

Золотые олени Евразии. Каталог выставки в Гос. Эрмитаже (СПб., 18.Х.2001 г. - 20.І.2002 г.), 2001. СПб. : Славия. $248 \mathrm{c.}$

Коллекции Филипповских курганов из фондов Музея археологии и этнографии ИЭИ УФИЦ РАН : каталог, 2018. Уфа : Китап. 400 с.

Королькова Е. Ф., 2006. Звериный стиль Евразии. Искусство племен Нижнего Поволжья и Южного Приуралья в скифскую эпоху (VII-IV вв. до н.э.). Проблемы стиля и этнокультурной принадлежности. СПб. : Петербургское Востоковедение. $272 \mathrm{c}$.

Королькова Е. Ф., 2018. Скифо-сибирский «звериный стиль» и Филипповские курганы // Коллекции Филипповских курганов из фондов Музея археологии и этнографии ИЭИ УФИЦ РАН : каталог. Уфа : Китап. C. $31-38$.

Переводчикова Е. В., 2012. К вопросу о месте производства золотых оковок деревянных сосудов из Филипповки // Музейні читання : матеріали наукової конференції “Ювелірне мистецтво - погляд крізь віки”. Київ : Музей історичних коштовностей України. С. 93-104.

Переводчикова Е. В., 2016а. Золотые оковки деревянных сосудов из 1-го Филипповского кургана // Российская археология. № 2. С. 19-35.

Переводчикова Е. В., 2016б. О стилистическом единстве произведений звериного стиля из 1-го Филипповского кургана // Урал-Алтай: через века в будущее : материалы VII Всерос. тюркологич. конф. (с междунар. участием), посвящ. 95-летию видного ученого-тюрколога Э.Р. Тенишева. Уфа : ИИЯЛ УНЦ РАН. С. 220-222.

Переводчикова Е. В., 2017. Гривна с изображениями в зверином стиле из кургана 3 у с. Кичигино // Этнические взаимодействия на Южном Урале. Сарматы и их окружение : материалы VII Bсерос. (с междунар. участием) науч. конф. Челябинск : Государственный исторический музей Южного Урала. С. 106-110.

Пшеничнюк А. Х., 2006. Звериный стиль Филипповских курганов // Южный Урал и сопредельные территории в скифо-сарматское время : сб. ст. к 70-летию Анатолия Харитоновича Пшеничнюка. Уфа : Гилем. C. 26-37.

Пшеничнюк А. Х., 2012. Филипповка. Некрополь кочевой знати IV в. до н.э. на Южном Урале. Уфа : ИИЯЛ УНЦРАН. $278 \mathrm{c}$.

Яблонский Л. Т., 2014а. Новые находки в «царском» кургане 1 могильника Филипповка 1 (предварительное сообщение) // Краткие сообщения Института археологии. Вып. 232. С. 3-7.

Яблонский Л. Т., 2014б. Новые находки в «царском» кургане 1 могильника Филипповка 1 (предварительное сообщение) // Труды IV (XX) Всероссийского археологического съезда в Казани. Т. II. Казань : Отечество. С. 194-198.

Яблонский Л. Т., 2014в. Отчет о доследовании кургана 1 могильника Филипповка 1 в 2013 году. Т. 1 // Архив ИА РАН. Р-1. № $41778.92 \mathrm{c}$. 
Яблонский Л. Т., 2014г. Отчет о доследовании кургана 1 могильника Филипповка 1 в 2013 году. Т. 2 // Архив ИА РАН. Р-1. № 41779. 168 c.

Яблонский Л. Т., 2016. Новые археологические данные об ахеменидских влияниях на Южном Урале // Вестник древней истории. № 3. С. 744-766.

The Golden Deer of Eurasia. Scythian and Sarmatian Treasures from the Russian Steppes, 2000. New York : The Metropolitan Museum of Art, Yale University Press. 393 p.

\section{REFERENCES}

Anikeeva O.V., Shemahanskaya M.S., Yablonsky L.T., 2017. Yuvelirnye shedevry ahemenidskoy epohi iz grobnicy znatnoy zhenshchiny v Yuzhnom Priural'e [Jewellery Chefs d'oeuvre of the Achaemenid époque from the Noble Woman Burial in Southern Ural]. Yuvelirnoe iskusstvo i material'naya kul 'tura [Art of Jewellery and Material Culture]. Saint Petersburg, The State Hermitage, pp. 5-11.

Anikeeva O.V., Natskiy M.V., Shemahanskaya M.S., Yablonsky L.T., 2018. Yuvelirnye ukrasheniya iz pogrebeniya znatnoy zhenshchiny (mogil'nik Filippovka 1, kurgan 1, pogrebenie 2) [Jewelry from the Burial of a Noble Woman (Kurgan Cemetery Filippovka 1 Kurgan 1 Burial 2)]. Duhovnaya modernizatsiya i arheologicheskoe nasledie: materialy Mezhdunar. nauch.-prakt. konf. «Margulanovskie chteniya-2018». Almaty-Aktobe, Institute of Archaeology named after A. Kh. Margulan, pp. 211-219.

Anikeeva O.V., Yablonsky L.T., 2018. Kustarnoe remeslo u rannih kochevnikov Yuzhnogo Urala [Southern Ural Early Nomadic Home Production]. XXI Ural'skoe arheologicheskoe soveshchanie, posvyashchennoe 85letiyu so dnya rozhdeniya G.I. Matveevoy i 70-letiyu so dnya rozhdeniya I.B. Vasil'eva: materialy Vseros. nauch. konf. s mezhdunar. uchastiem [XXI Ural Archaeological Consilium to the $85^{\text {th }}$ Anniversary of G.I. Matveeva and the $70^{\text {th }}$ Anniversary of I.B. Vasil'ev. Proceedings of the All-Russian Research Conference (with International Members)]. Samara, SSUSSE, pp. 189-193.

Anikeeva O.V., Yablonsky L.T., 2019. Materialy k rekonstruktsii zhenskogo pogrebal'nogo kostyuma iz elitnogo zahoroneniya rannih kochevnikov Yuzhnogo Priural'ya [Materials for the Reconstruction of the Female Funeral Costume from the Elite Burial of of Southern Ural Early Nomads]. Krym v sarmatskuyu epohu (II v. do n.e. $-I V$ v. n.e.): materialy X Mezhdunar. nauch. konf. "Problemy sarmatskoy arheologii $i$ istorii» [The Crimea in the Age of the Sarmatians (200 BC - AD 400). Proceedings of the $10^{\text {th }}$ International Research Conference "The Aspects of Sarmatian Archaeology and History"]. Simferopol', Salta LTD Publ., pp. 14-24.

Artamonov M.I., 1966. Sokrovishcha skifskih kurganov v sobranii Gosudarstvennogo Ermitazha [Tresures from the Scythian Kurgans in the State Hermitage Collection]. Praga; Leningrad, Artiya Publ., Sovetskiy hudozhnik Publ. 306 p.

Zolotye oleni Evrazii. Katalog vystavki v Gos. Ermitazhe (SPb., 18.X.2001 g. - 20.I.2002 g.), 2001 [The Golden Deer of Eurasia. Catalog of the Exhibition in State Hermitage (SPb., 18.X.2001 g. - 20.I.2002 g.)]. Saint Petersburg, Slaviya Publ. 248 p.

Kollektsii Filippovskih kurganov iz fondov Muzeya arheologii i etnografii IEI UFIC RAN: catalog, 2018 [The Filippovka Barrows Collections in the Museum of Archaeology and Ethnology of Institute of Ethnological Studies UFC RAS: Catalog]. Ufa, Kitap. 400 p.

Korol'kova E.F., 2006. Zverinyy stil' Evrazii. Iskusstvo plemen Nizhnego Povolzh'ya i Yuzhnogo Priural'ya v skifskuyu epohu (VII-IVvv. do n. e.). Problemy stilya i etnokul turnoy prinadlezhnosti [The Animal Style of Eurasia. The Art of the Lower Volga Region and the Southern Cisurals tribes in the Scythian Era $\left(7^{\text {th }}-4^{\text {th }} B C\right)$. Stylistic and Ethnocultural Problems]. Saint Petersburg, Peterburgskoe Vostokovedenie Publ. 272 p.

Korol'kova E.F., 2018. Skifo-sibirskiy «zverinyy stil'» i Filippovskie kurgany [Scythian-Siberian Animal Style and Filippovka Kurgans]. Kollektsii Filippovskih kurganov iz fondov Muzeya arheologii i etnografii IEI UFIC RAN: catalog [The Filippovka Barrows Collections in the Museum of Archaeology and Ethnology of Institute of Ethnological Studies UFC RAS: Catalog]. Ufa, Kitap, pp. 31-38.

Perevodchikova E.V., 2012. K voprosu o meste proizvodstva zolotyh okovok derevyannyh sosudov iz Filippovki [To the Question of the Place of Production of the Golden Plaques of Wooden Vessels from the 1 Filippovka Kurgan]. Muzeyni chitannya: materialy naukovoy konferentsiy "Yuvelirne mistectvo - poglyad kriz'viki", [The Museum Readings. The Materials of the Scientific Conference "Jewelry Craft. The Look Down the Ages"]. Kiev, Museum of historical treasures of Ukraine, pp. 93-104. 
Perevodchikova E.V., 2016a. Zolotye okovki derevyannyh sosudov iz 1-go Filippovskogo kurgana [Golden Plaques of Wooden Vessels from Filippovka $1^{\text {st }}$ Barrow]. Rossiyskaya arheologiya [Russian Archaeology], no. 2, pp. 19-35.

Perevodchikova E.V., 2016b. O stilisticheskom edinstve proizvedeniy zverinogo stilya iz 1-go Filippovskogo kurgana [On the Stylistic Unity of the Animal Style from the 1 Filippovka barrow]. Ural-Altay: cherez veka v budushchee: materialy VII Vseros. tyurkologich. konf. (s mezhdunar. uchastiem), posvyashch. 95-letiyu vidnogo uchenogo-tyurkologa E.R. Tenisheva [Ural-Altay: Cross the Ages to the Future. Proceedings of the AllRussian Turcological Conference (with International Members) to the $95^{\text {th }}$ Anniversary of the Outstanding Turcologist E.R. Tenishev]. Ufa, IHLL USC RAS, pp. 220-222.

Perevodchikova E.V., 2017. Grivna s izobrazheniyami v zverinom stile iz kurgana 3 u s. Kichigino [The Torque with the Images in Scythan Animal Style from Barrow no. 3 Near Kichigino Settlement]. Etnicheskie vzaimodeystviya na Yuzhnom Urale. Sarmaty i ih okruzhenie: materialy VII Vseros. (s mezhdunar. uchastiem) nauch. konf. [Ethnic Interactions in the South Ural. Sarmatians and their Environment. Proceedings of the $7^{\text {th }}$ All-Russian (with International Members) Research Conference]. Chelyabinsk, Gos. istoricheskiy muzey Yuzhnogo Urala, pp. 106-110.

Pshenichnyuk A.H., 2006. Zverinyy stil' Filippovskih kurganov [Animal Style of Filippovka Kurgans]. Yuzhnyy Ural $i$ sopredel'nye territorii $v$ skifo-sarmatskoe vremya: sb. st. $k$ 70-letiyu Anatoliya Haritonovicha Pshenichnyuka [Southern Ural and Adjacent Regions in Scythian-Sarmatian Time. The Collected Papers to the 70 ${ }^{\text {th }}$ Anniversary of Anatoliy Haritonovich Pshenichnyuk]. Ufa, Gilem, pp. 26-37.

Pshenichnyuk A.H., 2012. Filippovka. Nekropol'kochevoy znati IV v. do n.e. na Yuzhnom Urale [Filippovka. Nekropolis of the Nomad Nobility of the $4^{\text {th }}$ BC in the South Urals]. Ufa, IHLL USC RAS. 278 p.

Yablonsky L.T., 2014a. Novye nahodki v «tsarskom» kurgane 1 mogil'nika Filippovka 1 (predvaritel'noe soobshchenie) [New Finds in the "Royal" Burial-Mound 1 in the Filippovka 1 Cemetery (Preliminary Report)]. Kratkie soobshcheniya Instituta arheologii [Brief Communications of the Institute of Archaeology], iss. 232, pp. 3-7.

Yablonsky L.T., 2014b. Novye nahodki v «tsarskom» kurgane 1 mogil'nika Filippovka 1 (predvaritel'noe soobshchenie) [New Finds in the "Royal" Burial-Mound 1 in the Filippovka 1 Cemetery (Preliminary Report)]. Trudy IV (XX) Vserossiyskogo arheologicheskogo s'ezda v Kazani [Proceedings of the IV (XX) All-Russian Archaeological Congress in Kazan], vol. II. Kazan', Otechestvo Publ., pp. 194-198.

Yablonsky L.T., 2014v. Otchet o dosledovanii kurgana 1 mogil'nika Filippovka 1 v 2013 godu [Report on Supplementary Excavations of Kurgan 1 Filippovka 1 Cemetery in 2013], vol. 1. Arhiv IA RAN. R-1. № 41778. $92 \mathrm{p}$.

Yablonsky L.T., 2014g. Otchet o dosledovanii kurgana 1 mogil'nika Filippovka 1 v 2013 godu [Report on Supplementary Excavations of Kurgan 1 Filippovka 1 Cemetery in 2013], vol. 2. Arhiv IA RAN. R-1. № 41779. $168 \mathrm{p}$.

Yablonsky L.T., 2016. Novye arheologicheskie dannye ob ahemenidskih vliyaniyah na Yuzhnom Urale [New Archaeological Data on the Achaemenid Influence in the Southern Ural Area]. Vestnik drevney istorii [Journal of Ancient History], no. 3, pp. 744-766.

The Golden Deer of Eurasia. Scythian and Sarmatian Treasures from the Russian Steppes, 2000. New York, The Metropolitan Museum of Art, Yale University Press. 393 p. 


\section{Information About the Authors}

Konstantin S. Okorokov, Specialist, Institute of Archaeology of the Russian Academy of Sciences, Dm. Ulianova St., 19, 117292 Moscow, Russian Federation, okorokov.arx@mail.ru, https://orcid.org/0000-0001-7060-6313

Elena V. Perevodchikova, Candidate of Sciences (History), Scientific Researcher, Institute of Archaeology of the Russian Academy of Sciences, Dm. Ulianova St., 19, 117292 Moscow, Russian Federation, perevelena@yandex.ru, https://orcid.org/0000-0003-2780-5450

\section{Информация об авторах}

Константин Сергеевич Окороков, специалист, Институт археологии РАН, ул. Дм. Ульянова, 19, 117292 г. Москва, Российская Федерация, okorokov.arx@mail.ru, https://orcid.org/0000-0001-7060-6313

Елена Владимировна Переводчикова, кандидат исторических наук, научный сотрудник, Институт археологии РАН, ул. Дм. Ульянова, 19, 117292 г. Москва, Российская Федерация, perevelena@yandex.ru, https://orcid.org/0000-0003-2780-5450 